\title{
A Risk Analysis and Ranking Application for Lifting Vehicles Used in Construction Sites with Integrated AHP and Fine-Kinney Approach
}

\author{
Fatih Yilmaz ${ }^{1}$, Mehmet Selim Ozcan ${ }^{2}$ \\ 1 Department of Labour Economics and Industrial Relations, Bandirma Onyedi Eylul University, Merkez \\ Yerleske, 10200, Balikesir, Turkey \\ 2 Department of Mechanical Engineering, Yildiz Technical University, Besiktas, 34349, Istanbul, Turkey \\ * Corresponding author's e-mail: fatihyilmaz@bandirma.edu.tr
}

\begin{abstract}
Risk scoring methods applied in risk assessments used in Turkey, differ from each other in terms of analysis methods, scoring the risks, presumption and sensitivity levels. This article aims to eliminate the effects of divergent results of different risk analyses of lifting equipments used in the building industry and develop a practical hybrid risk analysis and ranking method. In this study risks of lifting equipments used in the building industry were scored by conventional Fine-Kenney risk analysis method first. Secondly, with the experience of previous accidents on construction sites, the reasons of accidents were sorted into 7 main criteria, which being 'Demographic', 'Behavioral', 'Machine Related', 'Working Environment Related', 'Economical', 'Administrative' and 'Organizational' criteria and related sub-criteria. Developing these criteria was supported by the experience of inspections carried out by labour inspectors. The weighted scores of these criteria were calculated by AHP method using a questionnaire applied to 14 experienced labor inspectors. The weighted scores obtained by the analytical hierarchy process method (AHP) were multiplied by the scores obtained by Fine-Kinney risk assessment method and a new integrated risk assessment and ranking application was introduced. With this application, a different priority rank was created and which risk to be eliminated primarily was determined.
\end{abstract}

Keywords: analytical hierarchy process, lifting equipments, fine-kinney, occupational health and safety, integrated risk analysis, ranking method

\section{INTRODUCTION}

In recent years, the importance of construction has increased in the Turkish economy. According to TURKSTAT data, the ratio of construction sector in national income was $8.1 \%$ in $2014,8.2 \%$ in 2015 and $8.6 \%$ in 2016 . However, most of the fatal accidents occur in the construction sector inTurkey. According to Social Insurance Institution data, approximately 35\% of deaths experienced in the construction sector every year. One of the most important reasons of serious accidents in construction cites is the lifting vehicles. These accidents also cause huge financial losses. Most of these accidents are easily prevented by calculating risks accurately based on risk assessment results.
With the Law No. 6331 (OH\&S Act), risk assessment was made compulsory in all workplaces in Turkey in 2013. Widely used risk assessment methods on construction sites in Turkey are conventional '5x5 Matrix' (Matrix L) and 'Fine-Kinney' risk assessment methods. These methods are criticized because they contain subjective evaluations. Risk scores calculated in these risk assessment methods, the confidence level remains low depending on the person's knowledge and experience that the risk assessment. The success of the risk assessments made by these methods depends on the knowledge and experience of the expert. This reduces the success of these methods in calculating risks.

Multi-criteria decision making (MCDM) is a commonly used method to solve problems that 
arise when there are many criteria in the decisionmaking process. MCDM methods are frequently used in the solution of occupational health and safety problems and risk assessment studies. In this study, it is aimed to integrate Fine-Kinney method with AHP method. Firstly, the risks arising from the lifting vehicles were analyzed and scored by Fine-Kinney risk assessment method. In the second stage the weights of the hazard criterias were calculated by Analytical Hierarchy Process (AHP) method. At the last stage, the risk ranking was formed by multiplying the Fine-Kinney risk scores with the global weighted scores of each sub-criterion.

The main and sub-criteria used in the calculation of risk scores were determined by examining 1800 occupational accidents between 2015-2018 which resulted mortality. These main hazard criteria include; 'demographic', 'behavioral', 'working environment', 'machinery', 'organizational', 'managerial', 'economic' and their sub-criteria.

The data used in calculation of the weighted scores of hazard criteria with AHP method was obtained with a questionnaire applied to experienced labor inspectors. Global weighted scores of each sub-criterion were integrated into the FineKinney risk analysis and the current risks were ranked according to the new risk scores and presented in a comparative chart.

The aim of the study is to increase the numerical sensitivity of risk scores obtained in traditional risk analysis methods, to determine different risk scores for the hazards calculated with the same risk scores as Fine-Kinney, and to determine a ranking in terms of the measures to be taken for these hazards. Thus, it is aimed to provide a guiding tool for occupational safety experts, managers and employers in order to determine the order of occupational health and safety measures in workplaces and to help planning the occupational health and safety measures.

\section{RESEARCH METHODS}

\section{Analytical Hierarchy Process Method}

In order to rank the alternatives or to choose the most suitable alternative, the process of evaluating the existing alternatives using quantitative and qualitative criteria is defined as multi-criteria decision making. The aim of the process is to find the most suitable option among the identified alternatives. Since multi-criteria decision making is used to rank alternatives with more than one criterion, it is a frequently used method to solve problems that occur in situations where there are many criteria and conflicting situations in the decision-making process [9].

The Analytical Hierarchy Method (AHP) was introduced by Thomas L. Saaty in the 1970s to solve a specific programming problem. This hierarchical structure created with the AHP aims to making the best decision or choosing the best alternative in the top of the hierarchy. As the lower levels are reached, the features that contribute to the purpose and the details of these features are seen. Decision options creates the lowest level. AHP is a theory of measurement based on a double comparison of alternatives to a common criterion and provides significant assistance to decision makers for eliminating multi-choice and multi-criteria problems. AHP problems are formed by a hierarchical structure consisting of objectives, criteria, possible sub-criterion levels and alternatives for each problem [20,21].

Zhao [26] describes the AHP process in five steps:

- Step 1: Create a decision hierarchy by separating the problem into decision elements (attributes),

- Step 2: To compare the elements of decision to collect input,

- Step 3: Determining whether the input data is fulfilled with the 'Consistency Test'

- Step 4: Calculate the relative weight of decision elements,

- Step 5: Collect the weighted points of each decision element and list the decision alternatives.

This method has been used in many areas such as employee health, occupational safety, fire and performance measurement at workplaces. Multicriteria decision making and risk ranking methods are also frequently used in researches on occupational health and safety [3, 6, 11, 12, 13, 24].

Prior to this study, several studies on integrated risk assessment were carried out under different outlooks. Integrated risk assessment practices are frequently encountered in construction works [1, 2, 4, 10, 16, 17, 18, 19, 22, 23]. However, there are few studies conducted in other areas other than construction with the approach of AHP and Fine-Kinney. For example, in a large machine manufacturing company, an application 
was proposed with the integrated AHP FineKinney approach in the assessment of OHS risks [15]. The integrated AHP Fine-Kinney approach was also similarly used in assessing the risks in rail transport [7], in assessing the risks in the maintenance of ballast tanks [25]; and to identify and calculate the risk priority of each hazard in an arms manufacturing company [8]. However, in the literature, no risk assessment studies with AHP and Fine-Kinney approach related to lifting vehicles or construction works.

This study aimed to calculate the importance level of each hazard criterion according to the opinions of expert labor inspectors and to integrate the weighted risk scores calculated with AHP in Fine-Kinney risk analysis application. With this method, new and hybrid risk scores are calculated for the lifting tools used in construction sites. Thus, the existing risks are more sensitively ranked and the negative impacts that may arise from the knowledge and experience of the persons preparing the risk assessment are reduced.

With this method, the risks associated with lifting vehicles are calculated by quantitative method and the sensitivity of the risk assessment is increased. Quantitative information is provided to support occupational health and safety experts in determining the measures and priorities to be taken at the site and planning preventive studies.

\section{Fine-Kinney Risk Assessment Method}

Fine-Kinney method was first proposed in 1971 by Fine W.T. as a method of risk assessment based on mathematical calculation with a study called 'Mathematical Assessment for the Control of Hazards'. In 1976, Kinney G.F. and Wiruth A.D., further developed under the name of 'Practical Risk Analysis for Occupational Safety Management' [5, 14]. In Fine-Kinney method, as in other risk assessment methods, it is a technique used to determine the order of implementation of the measures according to the ranking of the risks and where to use the resources first. Unlike other methods, it takes into account the frequency scale by taking into account the frequency of occurrence of the hazards. The method is applied as a quantitative method and its reliability is increased according to qualitative methods.

In Fine-Kinney method, there are three risk scales: Probability (P), Frequency (F) and Severty (S). Numerical values corresponding to verbal expressions are used. In applying this method, the risk score is calculated by finding the numerical values related to the hazards from the tables and multiplying the values. According to the method, a hazard is calculated with the formula: Risk Score $(\mathrm{R})=$ Probability $(\mathrm{P}) \times$ Frequency $(\mathrm{F}) \times \mathrm{Se}-$ verty $(S)[5,14]$.

Probability in Fine-Kinney risk assessment method; the possibility of an undesirable hazard which may result damage in health or property. The probability values are graded between 0.1 and 10 and the probability value is determined by evaluating whether the measures taken in the workplace are sufficient to prevent the occurrence of damages.

Frequency is the frequency of exposure to a certain period of time. In the method, the frequency values are defined between 0.5 and 10 . When determining the frequency value, the frequency of exposure should be taken into consideration when doing the work, not the frequency of the work.

Severty is the estimated damage to human and/or the environment. In the method, the severity values are graded between 1 and 100 values, and if there is any doubt about the severity of the incident or if it is unstable, the higher score should be given.

Total Risk Score is obtained by multiplying the probability, frequency and severity values of the hazards at working areas. As shown in Table 1, the level of risk is determined by looking at the range of the risk score obtained. According to the

Table 1. Desicion and action based on risk level

\begin{tabular}{|c|c|c|l|}
\hline Rank & Risk Value & Decision & Action \\
\hline 1 & $\mathrm{R}<20$ & Acceptable Risk & $\begin{array}{l}\text { Emergency measures may } \\
\text { not be necessary }\end{array}$ \\
\hline 2 & $20<\mathrm{R}<70$ & Risk & Action plan must be taken \\
\hline 3 & $70<\mathrm{R}<200$ & Important Risk & $\begin{array}{l}\text { Must be carrefully monitored and } \\
\text { removed by annual action plan }\end{array}$ \\
\hline 4 & $200<\mathrm{R}<400$ & High Risk & $\begin{array}{l}\text { Should be eliminated by taking } \\
\text { into the short-term action plan }\end{array}$ \\
\hline 5 & $\mathrm{R}>400$ & Very High Risk & $\begin{array}{l}\text { Take immediate measures } \\
\text { by suspending work }\end{array}$ \\
\hline
\end{tabular}


results of risk scores, the measures to be taken and the priority order may be determined according to the principles of occupational health and safety.

\section{APPLICATION}

\section{Data Collection Method and Prioritization of the Hazards with Ahp}

In order to obtain data for AHP application within the scope of the research, the main hazard criteria and sub-criteria (hazards) were determined as a result of the examination of 1800 fatal accidents which occurred in construction sites between 2015-2018 and a questionnaire was prepared in order to calculate the weights of these criteria. The questionnaire is presented in a simplified way to compare the hazard criterias with each other, as shown in Table 2.

Responses were gathered in separate forms with personal interviews from highly experienced labor inspectors in the Ministry of Labor Department of Guidance and Inspection, who are experts in safety and occupational accidents and inspected at least 50 different enterprises each year.

After the hazards were determined and the categories were formed, each hazard was compared with itself using the AHP method, and AHP table was formed. While forming the AHP tables, the experience of an expert could be exploited, and the AHP comparison tables could be formed by one expert. If there is more than one expert, an assessment is made based on each expert and then the average AHP value of experts can be found using the arithmetic average of the AHP values of the experts.

In this study, the questionnaire was applied to 14 labor inspectors. The purpose and the nature of the questionnaire and its intended results are described in detail. Participants were asked to determine the degree of severity according to the other criterion specified at the end of the line. The AHP method was used to calculate the hazard criteria weights according to the scores in the questionnaire through the matrix. Calculation was made based on each expert and used arithmetic average of the AHP values of the experts.
In questionnaire; 'Mechanical Criteria', 'Economic Criteria', 'Behavioral Criteria', 'Work Environment Criteria', 'Administrative Criteria', 'Demographic Criteria' and 'Organizational Criteria' are presented in the form of comparative headings for the calculation of the weighted scores of the main hazard criteria and their sub-criteria.

In order to calculate the total relative weight of each hazard criterion, the main hazard criteria were divided into various criteria and compared with the surveys conducted by the labor inspectors. Then, the overall weighted average scores of all sub-criteria, the total weighted scores of the main criteria and the total weighted scores of the sub-criteria within the main criteria were calculated.

Hazard criteria weights calculated by AHP method are presented in Table 3:

\section{Integration of Ahp Method with Fine- Kinney Risk Assessment Method}

Firstly, the risk scores calculated by the FineKinney method are ranked from large to small according to the size of the risk scores. Then, the hazard definitions stated in the risk analysis table are divided into classes according to the criteria specified in the survey conducted by the labor inspectors. During this classification, more than 200 construction site audit experience and occupational accident statistics were used. The FineKinney risk score in the risk assessment table are multiplied by the global weight score of that criterion, which is the subclass category. The new risk scores updated with AHP are presented in tables according to their risk scores, including the scores obtained by the Fine-Kinney method, sorted by size (See Table 4 Risk score and ranking table prepared by integrated Fine-Kinney-AHP method).

The study was carried out as follows;

- In the first stage, hazards were categorized and risk scores were calculated by using the FineKinney method on lifting vehicles together with occupational safety experts in construction sites.

- In the second stage, by taking into account the accident statistics related to lifting vehicles,

Table 2. Two-way comparison scale

\begin{tabular}{|c|c|c|c|c|c|c|c|c|c|}
\hline $\mathrm{X}$ & 9 & 7 & 5 & 3 & 1 & 3 & 5 & 7 & 9 \\
\hline & $\begin{array}{c}\text { Absolute } \\
\text { Important }\end{array}$ & $\begin{array}{c}\text { Very } \\
\text { Important }\end{array}$ & Important & $\begin{array}{c}\text { Little } \\
\text { Important }\end{array}$ & Unimportant & $\begin{array}{c}\text { Little } \\
\text { Important }\end{array}$ & $\begin{array}{c}\text { Important } \\
\text { Impory }\end{array}$ & $\begin{array}{c}\text { Vbsolute } \\
\text { Important }\end{array}$ & $\begin{array}{l}\text { Important } \\
\text { Impory }\end{array}$ \\
\hline
\end{tabular}


the main hazard criteria related to lifting vehicles and their sub-criteria were determined.

- In the third stage, severity of these main and sub-criteria was determined by a questionnaire applied to 14 labor inspectors and results were calculated by AHP method. Weighted (significance) scores of each main criterion and sub criterion were determined.
- In the fourth stage, the weighted global (overall) scores calculated for each sub-criterion were multiplied by the risk scores calculated by the Fine-Kinney for each hazard.

- In the fifth stage, an integrated risk assessment score table was formed. The risks arising from the lifting equipment were ranked according to the risk score.

Table 3. Hazard criteria weights calculated by AHP

\begin{tabular}{|c|c|c|c|c|}
\hline $\begin{array}{c}\text { Main } \\
\text { Criteria }\end{array}$ & Sub-criteria & $\begin{array}{c}\text { Global (Overall) } \\
\text { Weighted Score of } \\
\text { Sub-Criteria }\end{array}$ & $\begin{array}{l}\text { Total Weighted } \\
\text { Score of Main } \\
\text { Criteria }\end{array}$ & $\begin{array}{c}\text { Weighted Score of } \\
\text { the Sub-Criteria in the } \\
\text { Main Criteria }\end{array}$ \\
\hline \multirow{5}{*}{ 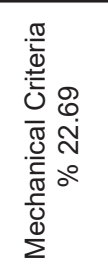 } & Design Errors & 0.079073041 & \multirow{5}{*}{0.226930437} & 0.348446165 \\
\hline & $\begin{array}{l}\text { Insufficiency of Periodic Controls of Lifting } \\
\text { Vehicles }\end{array}$ & 0.043122856 & & 0.19002676 \\
\hline & Lack of Machine Maintenance & 0.037396803 & & 0.164794125 \\
\hline & $\begin{array}{l}\text { Installation and Operation Information of the } \\
\text { Machine }\end{array}$ & 0.035854857 & & 0.157999332 \\
\hline & Malfunctions & 0.031482881 & & 0.138733618 \\
\hline \multirow{5}{*}{ 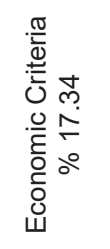 } & $\begin{array}{l}\text { Uncontrolled Growth of Construction Sector } \\
\text { (Lack of specialization) }\end{array}$ & 0.069953745 & \multirow{5}{*}{0.173460464} & 0.403283511 \\
\hline & Lack of Adaptation to Technology & 0.045694553 & & 0.26342921 \\
\hline & Budget Deficiency & 0.027276564 & & 0.157249457 \\
\hline & Income Level of Employees & 0.019408395 & & 0.111889443 \\
\hline & Wage System Mistakes & 0.011127208 & & 0.064148379 \\
\hline \multirow{8}{*}{ 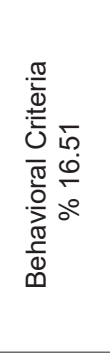 } & Lack of Awareness & 0.035100108 & \multirow{8}{*}{0.165157929} & 0.212524507 \\
\hline & Health problems & 0.026454907 & & 0.160179453 \\
\hline & Tiredness & 0.02484593 & & 0.150437406 \\
\hline & Inability & 0.024690546 & & 0.14949658 \\
\hline & Lack of Experience & 0.024064225 & & 0.14570433 \\
\hline & Family Problems & 0.01147748 & & 0.069493967 \\
\hline & Carelessness & 0.010087787 & & 0.061079643 \\
\hline & Lack of Motivation & 0.008436946 & & 0.051084113 \\
\hline \multirow{5}{*}{ 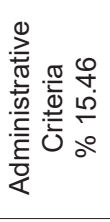 } & OHS Approach of Employer & 0.050936546 & \multirow{5}{*}{0.154660857} & 0.329343486 \\
\hline & Production Pressure & 0.043196415 & & 0.279297656 \\
\hline & Lack of Audit & 0.02382587 & & 0.154052363 \\
\hline & Discipline Deficiency & 0.020562678 & & 0.132953343 \\
\hline & Insufficiency of Penalties & 0.016139348 & & 0.104353151 \\
\hline \multirow{6}{*}{ 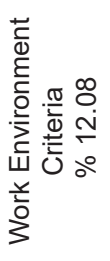 } & Hazardous Elements in the Working Area & 0.031065224 & \multirow{6}{*}{0.12081453} & 0.257131522 \\
\hline & Working Area Clutter & 0.028715163 & & 0.237679719 \\
\hline & Working Area Shortness & 0.0207752 & & 0.171959449 \\
\hline & Lack of Information on the Working Area & 0.017796858 & & 0.147307267 \\
\hline & Land Structure & 0.014717459 & & 0.121818617 \\
\hline & Climatic Effects & 0.007744625 & & 0.064103426 \\
\hline \multirow{6}{*}{ 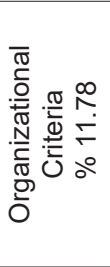 } & Lack of OHS Training & 0.033976084 & \multirow{6}{*}{0.117823218} & 0.288364931 \\
\hline & OHS Services Insufficiency & 0.022433729 & & 0.1904016 \\
\hline & Lack of Internal Audit and Supervision & 0.021587244 & & 0.183217235 \\
\hline & Lack of Communication & 0.019208973 & & 0.163032155 \\
\hline & Personnel Deficiency & 0.016219511 & & 0.137659716 \\
\hline & Lack of Documentation & 0.004397677 & & 0.037324363 \\
\hline \multirow{5}{*}{ 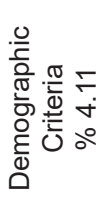 } & Education level & 0.015011851 & \multirow{5}{*}{0.041152566} & 0.364785289 \\
\hline & Working hours & 0.014978964 & & 0.363986143 \\
\hline & Migrant labor & 0.005738345 & & 0.139440752 \\
\hline & Age & 0.003681603 & & 0.089462305 \\
\hline & Gender & 0.001741803 & & 0.04232551 \\
\hline
\end{tabular}


Table 4. Risk score and ranking table prepared by integrated Fine-Kinney-AHP method

\begin{tabular}{|c|c|c|c|c|c|}
\hline $\begin{array}{l}\text { Ranking } \\
\text { with } \\
\text { Fine- } \\
\text { Kinney } \\
\end{array}$ & $\begin{array}{c}\text { Global (overall) weighted score } \\
\text { of sub-criterion } \\
\text { (GWS) }\end{array}$ & Definition of hazard & $\begin{array}{l}\text { Fine-Kinney } \\
\text { risk score } \\
\text { (FRS) }\end{array}$ & $\begin{array}{c}\text { Integrated risk } \\
\text { score (IRS) } \\
\text { IRS }= \\
\text { GWSxFRS } \\
\end{array}$ & $\begin{array}{l}\text { New } \\
\text { ranking }\end{array}$ \\
\hline 3 & $\begin{array}{l}0.0431228557110697 \text { (Insufficiency of } \\
\text { Periodic Controls) }\end{array}$ & Failure to check bolts & 3600 & 155.2422806 & 1 \\
\hline 1 & $\begin{array}{l}0.0207751999630086 \text { (Narrowness of the } \\
\text { Working Area) }\end{array}$ & $\begin{array}{l}\text { Working on the passageways } \\
\text { of the load }\end{array}$ & 6000 & 124.6511998 & 2 \\
\hline 2 & $\begin{array}{l}0.0207751999630086 \text { (Narrowness of the } \\
\text { Working Area) }\end{array}$ & Employees under load & 6000 & 124.6511998 & 3 \\
\hline 7 & $\begin{array}{l}0.0431228557110697 \text { (Insufficiency of } \\
\text { Periodic Controls) }\end{array}$ & Failure to control the brakes & 1800 & 77.62114028 & 4 \\
\hline 8 & $\begin{array}{l}0.0431228557110697 \text { (Insufficiency of } \\
\text { Periodic Controls) }\end{array}$ & $\begin{array}{l}\text { Hook and hook block not } \\
\text { controlled }\end{array}$ & 1800 & 77.62114028 & 5 \\
\hline 9 & $\begin{array}{l}0.0431228557110697 \text { (Insufficiency of } \\
\text { Periodic Controls) }\end{array}$ & $\begin{array}{l}\text { Chain and chain wheel not } \\
\text { controlled }\end{array}$ & 1800 & 77.62114028 & 6 \\
\hline 24 & 0.0790730405706215 (Design Errors) & $\begin{array}{l}\text { No warning signal on crane } \\
\text { movement }\end{array}$ & 900 & 71.16573651 & 7 \\
\hline 27 & 0.0790730405706215 (Design Errors) & $\begin{array}{l}\text { Lack of lighting of the load } \\
\text { hook }\end{array}$ & 900 & 71.16573651 & 8 \\
\hline 29 & 0.0790730405706215 (Design Errors) & Improper hooks & 900 & 71.16573651 & 9 \\
\hline 30 & 0.0790730405706215 (Design Errors) & Improper of ropes & 900 & 71.16573651 & 10 \\
\hline 31 & 0.0790730405706215 (Design Errors) & $\begin{array}{l}\text { Chains are not in accordance } \\
\text { with standards }\end{array}$ & 900 & 71.16573651 & 11 \\
\hline 39 & 0.0790730405706215 (Design Errors) & $\begin{array}{l}\text { Rope overrun out of the drum. } \\
\text { rope ejection }\end{array}$ & 900 & 71.16573651 & 12 \\
\hline 40 & 0.0790730405706215 (Design Errors) & Get rid of the rope from drum & 900 & 71.16573651 & 13 \\
\hline 41 & 0.0790730405706215 (Design Errors) & $\begin{array}{l}\text { Contact of the load on the } \\
\text { drum }\end{array}$ & 900 & 71.16573651 & 14 \\
\hline 43 & 0.0790730405706215 (Design Errors) & $\begin{array}{l}\text { The chain is not in accordance } \\
\text { with the standards }\end{array}$ & 900 & 71.16573651 & 15 \\
\hline 44 & 0.0790730405706215 (Design Errors) & $\begin{array}{l}\text { Lack of sieve ropes according } \\
\text { to the standards }\end{array}$ & 900 & 71.16573651 & 16 \\
\hline 45 & 0.0790730405706215 (Design Errors) & $\begin{array}{l}\text { Lack of steel ropes according } \\
\text { to the standards }\end{array}$ & 900 & 71.16573651 & 17 \\
\hline 46 & 0.0790730405706215 (Design Errors) & $\begin{array}{l}\text { Hooks do not comply with } \\
\text { standards }\end{array}$ & 900 & 71.16573651 & 18 \\
\hline 47 & 0.0790730405706215 (Design Errors) & $\begin{array}{l}\text { Slingshots not conforming to } \\
\text { standards }\end{array}$ & 900 & 71.16573651 & 19 \\
\hline 12 & $\begin{array}{l}0.0373968029068827 \text { (Lack of } \\
\text { Maintenance) }\end{array}$ & $\begin{array}{l}\text { Not performing the periodic } \\
\text { controls of the cranes }\end{array}$ & 1800 & 67.31424523 & 20 \\
\hline 18 & $\begin{array}{l}0.0373968029068827 \text { (Lack of } \\
\text { Maintenance) }\end{array}$ & $\begin{array}{l}\text { Failure to carry out necessary } \\
\text { checks after bad weather } \\
\text { conditions }\end{array}$ & 1800 & 67.31424523 & 21 \\
\hline 19 & $\begin{array}{l}0.0373968029068827 \text { (Lack of } \\
\text { Maintenance) }\end{array}$ & $\begin{array}{l}\text { Not performing required } \\
\text { periodic controls }\end{array}$ & 1800 & 67.31424523 & 22 \\
\hline 22 & $\begin{array}{l}0.0373968029068827 \text { (Lack of } \\
\text { Maintenance) }\end{array}$ & $\begin{array}{l}\text { Failure to periodic controls of } \\
\text { the elevator }\end{array}$ & 1800 & 67.31424523 & 23 \\
\hline 5 & $\begin{array}{l}0.0358548574518207 \text { (Inadequate } \\
\text { Machine Installation-Usage Information) }\end{array}$ & No grounding & 1800 & 64.53874341 & 24 \\
\hline 16 & $\begin{array}{l}0.0358548574518207 \text { (Inadequate } \\
\text { Machine Installation-Usage Information) }\end{array}$ & $\begin{array}{l}\text { Installation is not done by } \\
\text { experts }\end{array}$ & 1800 & 64.53874341 & 25 \\
\hline 17 & $\begin{array}{l}0.0358548574518207 \text { (Inadequate } \\
\text { Machine Installation-Usage Information) }\end{array}$ & $\begin{array}{l}\text { Failure to take safety } \\
\text { measures in crane installation }\end{array}$ & 1800 & 64.53874341 & 26 \\
\hline 21 & $\begin{array}{l}0.0358548574518207 \text { (Inadequate } \\
\text { Machine Installation-Usage Information) }\end{array}$ & No grounding & 1800 & 64.53874341 & 27 \\
\hline 6 & 0.0351001075428182 (Awareness) & Hooks without safety catch & 1800 & 63.18019358 & 28 \\
\hline 23 & 0.0351001075428182 (Awareness) & No fall protection equipment & 1800 & 63.18019358 & 29 \\
\hline 50 & 0.0790730405706215 (Design Errors) & $\begin{array}{l}\text { Lack of protective covers of } \\
\text { moving. dangerous points of } \\
\text { the crane }\end{array}$ & 750 & 59.30478043 & 30 \\
\hline 14 & $\begin{array}{l}0.0310652239332324 \text { (Elements in the } \\
\text { Study Area) }\end{array}$ & Power cut & 1800 & 55.91740308 & 31 \\
\hline
\end{tabular}


Table 4. cont.

\begin{tabular}{|c|c|c|c|c|c|}
\hline $\begin{array}{l}\text { Ranking } \\
\text { with } \\
\text { Fine- } \\
\text { Kinney } \\
\end{array}$ & $\begin{array}{c}\text { Global (overall) weighted score } \\
\text { of sub-criterion } \\
\text { (GWS) }\end{array}$ & Definition of hazard & $\begin{array}{l}\text { Fine-Kinney } \\
\text { risk score } \\
\text { (FRS) }\end{array}$ & $\begin{array}{c}\text { Integrated risk } \\
\text { score (IRS) } \\
\text { IRS= } \\
\text { GWSxFRS }\end{array}$ & $\begin{array}{l}\text { New } \\
\text { ranking }\end{array}$ \\
\hline 55 & 0.0790730405706215 (Design Errors) & $\begin{array}{l}\text { No protective parts in } \\
\text { electrical sections }\end{array}$ & 600 & 47.44382434 & 32 \\
\hline 4 & 0.0246905456069212 (Insufficiency) & $\begin{array}{l}\text { Using cranes by unauthorized } \\
\text { workers }\end{array}$ & 1800 & 44.44298209 & 33 \\
\hline 10 & 0.0240642253941192 (Experience) & $\begin{array}{l}\text { Interference when the crane is } \\
\text { in operation }\end{array}$ & 1800 & 43.31560571 & 34 \\
\hline 35 & $\begin{array}{l}0.0456945529320244 \text { (Compliance with } \\
\text { technology) }\end{array}$ & $\begin{array}{l}\text { Non-measurement of wind } \\
\text { speed }\end{array}$ & 900 & 41.12509764 & 35 \\
\hline 26 & $\begin{array}{l}0.0431228557110697 \text { (Lack of } \\
\text { Maintenance) }\end{array}$ & Insufficient braking & 900 & 38.81057014 & 36 \\
\hline 13 & $\begin{array}{l}0.0207751999630086 \text { (Narrowness of the } \\
\text { Working Area) }\end{array}$ & Entering under the load & 1800 & 37.39535993 & 37 \\
\hline 25 & $\begin{array}{l}0.0373968029068827 \text { (Lack of } \\
\text { Maintenance) }\end{array}$ & No controls of the crane & 900 & 33.65712262 & 38 \\
\hline 42 & $\begin{array}{l}0.0373968029068827 \text { (Lack of } \\
\text { Maintenance) }\end{array}$ & $\begin{array}{l}\text { Failure of chain controls. } \\
\text { working with defective chain }\end{array}$ & 900 & 33.65712262 & 39 \\
\hline 11 & $\begin{array}{l}0.0177968581680381 \text { (Information on the } \\
\text { Study Area - Warning Signs) }\end{array}$ & $\begin{array}{l}\text { Failure to take safety } \\
\text { measures in working } \\
\text { environment before working } \\
\text { with a crane }\end{array}$ & 1800 & 32.0343447 & 40 \\
\hline 15 & $\begin{array}{l}0.0177968581680381 \text { (Information on the } \\
\text { Study Area - Warning Signs) }\end{array}$ & Absence of warning signs & 1800 & 32.0343447 & 41 \\
\hline 20 & $\begin{array}{l}0.0177968581680381 \text { (Information on the } \\
\text { Study Area - Warning Signs) }\end{array}$ & $\begin{array}{l}\text { Not covered the area around } \\
\text { the elevator }\end{array}$ & 1800 & 32.0343447 & 42 \\
\hline 28 & 0.0351001075428182 (Awareness) & Not using safety clamp & 900 & 31.59009679 & 43 \\
\hline 32 & 0.0351001075428182 (Awareness) & $\begin{array}{l}\text { Using more than one crane on } \\
\text { the same construction site }\end{array}$ & 900 & 31.59009679 & 44 \\
\hline 49 & 0.0351001075428182 (Awareness) & $\begin{array}{l}\text { Leaving the used apparatus } \\
\text { on the hook }\end{array}$ & 750 & 26.32508066 & 45 \\
\hline 64 & 0.0790730405706215 (Design Errors) & $\begin{array}{l}\text { The drum does not comply } \\
\text { with standards }\end{array}$ & 300 & 23.72191217 & 46 \\
\hline 65 & 0.0790730405706215 (Design Errors) & $\begin{array}{l}\text { Rope ends are not connected } \\
\text { to the drum }\end{array}$ & 300 & 23.72191217 & 47 \\
\hline 53 & $\begin{array}{l}0.0373968029068827 \text { (Lack of } \\
\text { Maintenance) }\end{array}$ & $\begin{array}{l}\text { Exceeding speed limits on } \\
\text { lifting vehicles }\end{array}$ & 600 & 22.43808174 & 48 \\
\hline 38 & 0.0246905456069212 (Insufficiency) & $\begin{array}{l}\text { Giving bi-directional } \\
\text { movement }\end{array}$ & 900 & 22.22149105 & 49 \\
\hline 56 & $\begin{array}{l}0.0358548574518207 \text { (Inadequate } \\
\text { Machine Installation-Usage Information) }\end{array}$ & $\begin{array}{l}\text { Failure to take measures } \\
\text { when tower crane is not in use }\end{array}$ & 600 & 21.51291447 & 50 \\
\hline 37 & $\begin{array}{l}0.0207751999630086 \text { (Narrowness of the } \\
\text { Working Area) }\end{array}$ & $\begin{array}{l}\text { Lack of sufficient space for } \\
\text { Crane installation }\end{array}$ & 900 & 18.69767997 & 51 \\
\hline 36 & $\begin{array}{l}0.019208973057785 \text { (Lack of } \\
\text { communication) }\end{array}$ & $\begin{array}{l}\text { Miscommunication between } \\
\text { maneuverer and operator }\end{array}$ & 900 & 17.28807575 & 52 \\
\hline 48 & $\begin{array}{l}0.019208973057785 \text { (Lack of } \\
\text { communication) }\end{array}$ & $\begin{array}{l}\text { Lack of appropriate } \\
\text { communication equipment }\end{array}$ & 900 & 17.28807575 & 53 \\
\hline 54 & $\begin{array}{l}0.0272765637693887 \text { (Financial } \\
\text { insufficiency) }\end{array}$ & $\begin{array}{l}\text { Lack of sufficient capacity of } \\
\text { the crane }\end{array}$ & 600 & 16.36593826 & 54 \\
\hline 52 & 0.0240642253941192 (Experience) & $\begin{array}{l}\text { Uneducated slingshot and } \\
\text { maneuvering operators }\end{array}$ & 600 & 14.43853524 & 55 \\
\hline 60 & $\begin{array}{l}0.0373968029068827 \text { (Lack of } \\
\text { Maintenance) }\end{array}$ & Availability of control panel & 300 & 11.21904087 & 56 \\
\hline 63 & $\begin{array}{l}0.0373968029068827 \text { (Lack of } \\
\text { Maintenance) }\end{array}$ & Crane derailment & 300 & 11.21904087 & 57 \\
\hline 58 & $\begin{array}{l}0.0358548574518207 \text { (Inadequate } \\
\text { Machine Installation-Usage Information) }\end{array}$ & Exceeding crane capacity & 300 & 10.75645724 & 58 \\
\hline 59 & $\begin{array}{l}0.0358548574518207 \text { (Inadequate } \\
\text { Machine Installation-Usage Information) }\end{array}$ & $\begin{array}{l}\text { Non-conformance of drum } \\
\text { channel to standards }\end{array}$ & 300 & 10.75645724 & 59 \\
\hline 61 & $\begin{array}{l}0.0358548574518207 \text { (Inadequate } \\
\text { Machine Installation-Usage Information) }\end{array}$ & Lack of instruction manual & 300 & 10.75645724 & 60 \\
\hline
\end{tabular}


Table 4. cont.

\begin{tabular}{|c|c|c|c|c|c|}
\hline $\begin{array}{l}\text { Ranking } \\
\text { with } \\
\text { Fine- } \\
\text { Kinney } \\
\end{array}$ & $\begin{array}{c}\text { Global (overall) weighted score } \\
\text { of sub-criterion } \\
(\mathrm{GWS})\end{array}$ & Definition of hazard & $\begin{array}{l}\text { Fine-Kinney } \\
\text { risk score } \\
\text { (FRS) }\end{array}$ & $\begin{array}{c}\text { Integrated risk } \\
\text { score (IRS) } \\
\text { IRS= } \\
\text { GWSxFRS }\end{array}$ & $\begin{array}{l}\text { New } \\
\text { ranking }\end{array}$ \\
\hline 67 & $\begin{array}{l}0.0358548574518207 \text { (Inadequate } \\
\text { Machine Installation-Usage Information) }\end{array}$ & $\begin{array}{l}\text { The floor where the elevator } \\
\text { is placed does not meet the } \\
\text { standards }\end{array}$ & 300 & 10.75645724 & 61 \\
\hline 68 & $\begin{array}{l}0.0358548574518207 \text { (Inadequate } \\
\text { Machine Installation-Usage Information) }\end{array}$ & Exceeding elevator capacity & 300 & 10.75645724 & 62 \\
\hline 69 & $\begin{array}{l}0.0358548574518207 \text { (Inadequate } \\
\text { Machine Installation-Usage Information) }\end{array}$ & $\begin{array}{l}\text { The floor where the crane } \\
\text { is placed does not meet the } \\
\text { standards }\end{array}$ & 300 & 10.75645724 & 63 \\
\hline 70 & $\begin{array}{l}0.0358548574518207 \text { (Inadequate } \\
\text { Machine Installation-Usage Information) }\end{array}$ & $\begin{array}{l}\text { The control panel is not } \\
\text { available and is not available } \\
\text { to an authorized person }\end{array}$ & 300 & 10.75645724 & 64 \\
\hline 51 & $\begin{array}{l}0.0177968581680381 \text { (Information on the } \\
\text { Study Area - Warning Signs) }\end{array}$ & $\begin{array}{l}\text { No safety instructions. no } \\
\text { warning signs }\end{array}$ & 600 & 10.6781149 & 65 \\
\hline 57 & $\begin{array}{l}0.0177968581680381 \text { (Information on the } \\
\text { Study Area - Warning Signs) }\end{array}$ & $\begin{array}{l}\text { No safety instructions. no } \\
\text { warning signs }\end{array}$ & 600 & 10.6781149 & 66 \\
\hline 62 & 0.0351001075428182 (Awareness) & $\begin{array}{l}\text { Lack of sufficient illumination. } \\
\text { no visibility }\end{array}$ & 300 & 10.53003226 & 67 \\
\hline 71 & $\begin{array}{l}0.0358548574518207 \text { (Inadequate } \\
\text { Machine Installation-Usage Information) }\end{array}$ & The misuse of the crane & 200 & 7.17097149 & 68 \\
\hline 72 & $\begin{array}{l}0.0358548574518207 \text { (Inadequate } \\
\text { Machine Installation-Usage Information) }\end{array}$ & The misuse of the elevator & 200 & 7.17097149 & 69 \\
\hline 33 & 0.00774462528474803 (Climatic Effects) & Stormy weather essentials & 900 & 6.970162756 & 70 \\
\hline 34 & 0.00774462528474803 (Climatic Effects) & $\begin{array}{l}\text { Wind speed exceeds working } \\
\text { conditions }\end{array}$ & 900 & 6.970162756 & 71 \\
\hline 66 & 0.00774462528474803 (Climatic Effects) & Lightning & 300 & 2.323387585 & 72 \\
\hline 73 & 0.0351001075428182 (Awareness) & Leaving material suspended & 50 & 1.755005377 & 73 \\
\hline
\end{tabular}

\section{Findings}

Integrated risk scores of the Fine-Kinney and AHP methods are presented in Table 4. The table shows the ranking of the scores when multiplied by the global (overall) weights calculated for the sub-criterion with the first risk score calculated with Fine-Kinney. Integrated risk scores were calculated with this formula:

\section{Integrated Risk Score (IRS) = Global \\ (Overall) Weighted Score of Sub-criterion \\ $(G W S) \times$ Fine-Kinney Risk Score $(F R S)$}

Significant differences were found between the integrated risk ranking application and the risk ranking calculated by the Fine-Kinney method. For example, according to the FineKinney method, a hazard (Failure to check bolts) in the third rank was increased to the first rank. Similarly, in the Fine-Kinney method, the 24th hazard was placed in the 7th rank (no warning signal in crane movement), the 27 th ranked danger ranked 8th (Lack of lighting of the load hook), and the 29th ranked danger ranked 9th (Improper hooks).
On the other hand, in the Fine-Kinney table, the hazard in 5th (No grounding) is placed in 24th rank, the 12th hazard (Not performing the periodic controls of the cranes) is placed 20th, the 6 th hazard (Hooks without safety catch) is placed 28th and the 4th hazard (Using cranes by unauthorized workers) is placed 33rd.

However, as seen in the first 6 lines of Table 4, there is no significant difference in both FineKinney rankings and after ranking AHP application for the hazards where very high risk score is calculated. In the case of Fine-Kinney, 3rd hazard was placed in the 1 st rank and the 1st hazard was in 2 nd place. In the same way, the 2 nd hazard in the Kinney method was placed in the third rank, and the 7 th rank was in the 4th rank.

The same applies to hazards with low risk scores. For example, hazards such as 'uneducated slingshot and maneuvering operators', 'lack of appropriate communication equipment', and 'the inability of the control panel to be used', have been found to be lower in the Fine-Kinney method and have not been able to up higher risk scores for AHP-determined scores. 
The applied method does not increase the insignificant risks to a very high degrees or does not reduce a significant hazard to the low rankings. These results also show us that the applied risk ranking method does not provide manipulative results for high risks which may have really vital consequences.

Another important result we have obtained with this method is that, there may be a risk score difference between the hazards that take the same risk scores with traditional methods. In the Fine-Kinney method, the number of hazards with 1800 risk points is 20 , the number of hazards with 900 points is 24 , and the number of hazards with 600 points is 7 . These hazards in the same risk score were also graded according to the risk score with this method. Thus, the sensitivity of the risk assessment methods and the ability to rate risks have been increased with the method we have applied.

\section{CONCLUSIONS}

Lifting vehicles used in construction sites cause many fatal accidents. Within the scope of this study, the Fine-Kinney method was integrated with AHP and a new risk assessment was applied for the lifting vehicles. The risk scores were recalculated and ranked. Thus, the defects of the Fine-Kinney method were desired to be reduced. As a result of the application, the risk scores of many hazard criteria changed and many risks with the same score had different risk scores and the priorities was changed. As a result of the application, the hazards related to machines such as 'design errors', 'failure of periodic controls' and 'lack of maintenance' were found to be more important and priority. 'Behavioral criteria' including personal deficiencies such as 'lack of awareness' and 'inadequacy' were followed by high risk scores. 'Managerial errors' and 'working environment' have also been identified as another important causes of accidents.

\section{REFERENCES}

1. Abdelgawad M. and Fayek A. R. Risk management in the construction industry using combined fuzzy FMEA and fuzzy AHP. Journal of Construction Engineering and Management ASCE, 136(9), 2010, 1028-136.

2. Ahmadi M., Behzadian K., Ardeshir A. and Kapelan, Z. Comprehensive risk management using fuzzy fmea and mcda techniques in highway construction projects. Journal of Civil Engineering and Management, 23(2), 2017, 300-310.

3. Alkoc A. and Yilmaz F. Analysis of the risk arising from fire installations in manufacturing facilities by ranking method. Karaelmas Journal of Occupational Health and Safety, 2 (1), 2018, 1-11.

4. Ardeshir A. and Mohajeri M. Assessment of safety culture among job positions in high-rise construction: a hybrid fuzzy multi criteria decision-making (FMCDM) approach. International Journal of Injury Control and Safety Promotion, 25(2), 2018, 195-206.

5. Fine W. T. Mathematical evaluation for controlling hazards. Journal of Safety Research, 3(4), 1971, 157-166.

6. Guozhong Z., Neng Z., Zhe T., Ying C. and Bingul S. Application of a trapezoidal fuzzy AHP method for work safety evaluation and early warning rating of hot and humid environments. Safety Science, 50, 2012, 228-239.

7. Gul M. and Celik E. Fuzzy rule-based Fine-Kinney risk assessment approach for rail transportation systems. Human and Ecological Risk Assessment: An International Journal, 24(7), 2018, 1786-1812.

8. Gul M., Guven B. and Guneri A.F. A new FineKinney-based risk assessment framework using FAHP-FVIKOR incorporation. Journal of Loss Prevention in the Process Industries, 53, 2017, 3-16.

9. Gulsun B. and Yilmaz F. Calisma ortamina uygun zemin yapisinin cok kriterli karar verme yontemi (AHP) ile secimi. Uluslararası Hakemli İs Guvenligi ve Calisan Sagligi Dergisi, 1, 2016, 39-54.

10. Gurcanli E.G. and Mungen, U. An occupational safety risk analysis method at construction sites using fuzzy sets. International Journal of Industrial Ergonomics, 39, 2009, 371-387.

11. Jovcić S., Prusa P. and Nikolicic S. Evaluation criteria of the belt conveyor using the AHP method and selection of the right conveyor by Hurwitz method. Advances in Science and Technology Research Journal, 12(2), 2018, 137-143. DOI: $10.12913 / 22998624 / 92092$

12. Huang Y. F., Hsu K. H., Chein P. S. and Dong S. H. Discussing performance index of human resource valuation with AHP-occupational safety section in T company in Taiwan as the case study. Information Technology Journal, 10, 2011, 549-556.

13. Kim D. I., Yoo W. S., Cho H. and Kang K. I. A fuzzy AHP-based decision support model for quantifying failure risk of excavation work. KSCE Journal of Civil Engineering, 18, 2014, 1966-1976.

14. Kinney G. F. and Wiruth A. D. Practical risk analysis for safety management. Kaliforniya Naval Weapons Centre Technical Publication, 1976. 
15. Kokangul A., Polat U. and Dagsuyu C. A new approximation for risk assessment using the AHP and Fine Kinney methodologies. Safety Science, 91, 2017, 24-32.

16. Kuo Y.C. and Lu S.T. Using fuzzy multiple criteria decision making approach to enhance risk assessment for metropolitan construction projects. International Journal of Project Management, 31(4), 2013, 602-614.

17. Liu H.T. and Tsai Y. A fuzzy risk assessment approach for occupational hazards in the construction industry, Safety Science, 50, 2012, 1067-1078.

18. Pinto A., Nunes I.L. and Riberio R.A. Occupational risk assessment in construction industry-Overview and reflection. Safety Science, 49, 2011, 616-624.

19. Raviv G., Shapira A. and Fishbain B. AHP-based analysis of the risk potential of safety incidents: Case study of cranes in the construction industry. Safety Science, 91, 2016, 298-309.

20. Saaty L. T. How to make a decision: the analytic hierarchy process. European Journal of Operational Research, 48, 1990, 9-26.
21. Saaty L.T. Multi criteria decision making: the analytical hierarchy process. McGraw-Hill, New York, 1980.

22. Sousa V., Almeida N.M. and Dias L.A. Risk-based management of occupational safety and health in the construction industry-Part 2: Quantitative model. Safety Science, 74, 2015, 184-194.

23. Taylan O., Bafail A.O., Abdulaal R.M. and Kabli M.R. Construction projects selection and risk assessment by fuzzy AHP and fuzzy TOPSIS methodologies. Applied Soft Computing, 17, 2014, 105-116

24. Yilmaz F. and Alp S. Underlying factors of occupational accidents: the case of Turkey. Open Journal of Safety Science and Technology, 6, 2016, 1-10.

25. Wang W., Liu X. and Qin Y. A fuzzy Fine-Kinneybased risk evaluation approach with extended MULTIMOORA method based on Choquet integral. Computers \& Industrial Engineering, 125, 2018, 111-123.

26. Zhao C.M., Lo S.M., Lu J.A. and Fang Z. A simulation approach for ranking of fire safety attributes of existing buildings. Fire Safety Journal, 39, 2004, 557-579. 